\title{
SELEKSI KETAHANAN ANGGREK TERHADAP Odontoglossum ringspot virus (ORSV)
}

\author{
Irni Yuni Minarni, Mahfut*, Sri Wahyuningsih, \\ Tundjung Tripeni Handayani \\ Jurusan Biologi
}

Fakultas Matematika dan Ilmu Pengetahuan Alam Universitas Lampung

Jl. Prof. Dr. Sumantri Brojonegoro No. 1, Kota Bandar Lampung, Lampung. 35144

"E-mail: mahfut.mipa@fmipa.unila.ac.id

\begin{abstract}
Abstrak: Anggrek (Orchidaceae) merupakan salah satu tanaman hias yang digemari karena bentuk dan warna bunganya yang bervariasi serta dapat digunakan sebagai bunga potong, tanaman pot, atau elemen taman. Penyakit infeksi masih menjadi kendala utama dalam budidaya tanaman anggrek di Indonesia. Odontoglossum ringspot virus (ORSV) merupakan salah satu jenis virus yang paling banyak dilaporkan menginfeksi tanaman anggrek dan tersebar luas di dunia, termasuk di Indonesia. Infeksi menyebabkan perubahan warna dan bentuk daun serta bunga. Penelitian ini dilakukan dengan menginjeksi virus secara mekanis pada anggrek Phalaenopsis amabilis atau Dendrobium Salaya Fancy. Penelitian ini bertujuan untuk mengetahui gejala dan terjadinya penyakit, serta ketahanan anggrek terhadap ORSV. Hasil penelitian menunjukkan bahwa setiap anggrek memiliki gejala penyakit yang parah, tingkat keparahan penyakit pada kedua tanaman anggrek sekitar $80 \%$ serta reaksi Phalaenopsis amabilis sangat rentan dan respon Dendrobium Salaya Fancy toleran terhadap ORSV. Hal ini membuktikan bahwa Phalaenopsis merupakan jenis virus anggrek yang paling mudah terinfeksi dibandingkan Dendrobium.
\end{abstract}

Kata Kunci: anggrek, Odontoglossum ringspot virus, gejala, kejadian penyakit, ketahanan tanaman

\section{PENDAHULUAN}

I

ndonesia memiliki keanekaragaman spesies anggrek yang sangat besar. Diperkirakan 5.000 spesies anggrek telah tersebar di Indonesia. Anggrek mempunyai nilai tinggi karena bentuk, warna bunga serta karakteristik lainnya yang unik sehingga banyak diminati oleh konsumen (Mahfut, 2020). Anggrek secara alami hidup menempel di dahan pohon. Sebagian anggrek sangat peka terhadap ketinggian tempat dikarenakan perbedaan ketinggian tempat memiliki suhu udara yang berbeda. Tumbuhan dapat hidup dengan baik apabila lingkungan mampu menyediakan berbagai keperluan untuk pertumbuhan selama daur hidupnya. Oleh karena sifat lingkungan tidak hanya bergantung pada kondisi fisik dan kimia tetapi juga karena organisme lain (Matthews, 1992; Muharam et al., 2013; Koh et al., 2014).

Tanaman anggrek dalam pertumbuhannya mendapatkan gangguan penyakit seperti jamur patogen, bakteri, maupun virus. Gejala yang ditimbulkan seperti busuk hitam, busuk akar, layu, busuk lunak, bercak daun, mosaik, dan ringspot. Infeksi virus pada tumbuhan anggrek yaitu yang paling umum diamati adalah mosaik, nekrosis, nekrotik, 
dan klorotik (Navalienskie et al., 2005). Selain itu dijumpai gejala curling leaf dan wilting leaf. Sejumlah virus yang sudah menginfeksi tanaman anggrek sudah teridentifikasi adalah ORSV (Mahfut \& Daryono, 2019; Mahfut, 2020; Mahfut \& Anggraeni, 2020). Virus yang menginfeksi anggrek tidak mematikan tetapi menyebabkan daya tahan tanaman melemah sehingga memudahkan datangnya penyakit susulan. Tanaman anggrek yang telah terinfeksi virus tidak bisa dieridikasi dengan pestisida, hanya dapat diatasi dengan membakar anggrek dan mensterilkan kembali area tanam. Infeksi virus memiliki kisaran inang yang berbeda jenis tanaman. Penelitian ini dilakukan untuk memberikan rekomendasi daerah endemik infeksi virus terhadap pemilihan jenis anggrek yang tahan terhadap infeksi ORSV.

\section{METODE PENELITIAN}

Penelitian ini menggunakan penelitian deskriptif eksploratif yang dilakukan menggunakan inokulum virus ORSV dari isolat Magelang yang sudah dianalisis sebelumnya (Mahfut et al., 2016). Inokulasi dilakukan pada tanaman indikator dan tanaman inang. Selanjutnya dilakukan pengamatan gejala penyakit, kejadian penyakit, dan tingkat ketahanan tanaman.

Alat-alat yang digunakan dalam penelitian ini adalah: spidol permanen, gelas ukur, spektrofotometer UV, kuvet, kertas whatman no.1, flakon, mortar, alu, cawan petri, erlenmeyer, corong, tabung reaksi, sentrifuge, kertas label, selotip, penggaris, gunting, sarung tangan, tissu kering, plastik bening, karet gelang, botol semprot, polybag, pena, buku catatan dan kamera digital. Bahan yang digunakan adalah: tembakau (Nicotiana tabacum), tomat (Solanum lycopersicum), timun (Cucumis sativus), anggrek Phalaenopsis amabilis, anggrek Dendrobium Salaya Fancy, inokulum virus, karborundum 400 mesh, air, etanol, dan media tanam.

Penelitian ini meliputi 6 tahap yaitu: 1) Proses perkecambahan; 2) Penanaman kecambah tanaman indikator pada media tanah; 3) Seleksi inokulum virus; 4) Inokulasi virus pada tanaman indikator; 5) Inokulasi virus pada tanaman inang; 6) Pengamatan.

1. Proses perkecambahan: biji masing-masing tanaman indikator dikecambahkan dengan cara merendam biji dengan air selama 4 jam. Biji kemudian ditiriskan dan dibersihkan dengan air mengalir lalu diletakkan diatas cawan petri yang dilapisi beberapa lembar tisu lembab. Selanjutnya untuk menjaga kelembabannya dengan cara memercikkan air pada pagi hari dan sore hari. Biji yang sudah diletakkan pada cawan petri diletakkan ditempat gelap. 3 atau 4 hari berselang, biji mulai berkecambah. Pada hari ke 7 kotiledon telah membuka dan biji siap untuk ditanam di media tanah.

2. Penanaman kecambah tanaman indikator pada media tanah: persiapan media tanah pada penelitian ini diberi 4 perlakuan yaitu kontrol, ulangan 1, ulangan 2, dan ulangan 3 pada masing-masing jenis tanaman.

3. Seleksi inokulum virus: seleksi inokulum diperoleh dari hasil inokulasi isolat Magelang pada tanaman tembakau.

4. Inokulasi virus pada tanaman indikator: virus yang sudah diidentifikasi, selanjutnya diinokulasi ke tanaman indikator dan dilakukan dalam 4 kali ulangan. Pengamatan dilakukan dengan mencatat waktu saat inkubasi dan gejala yang muncul setelah inokulasi. Tanaman indikator yang terinfeksi lebih cepat dan menunjukkan gejala yang paling parah akan diambil dan diinokulasikan pada tanaman inang. Tahapan untuk inokulasi virus secara mekanik yaitu tahapan pertama ditimbang $1 \mathrm{~g}$ daun tembakau yang merupakan sumber inokulasi virus, kemudian daun digerus dalam mortar steril dengan menambahkan $10 \mathrm{ml}$ larutan penyangga fosfat atau buffer fosfat 
$0,01 \mathrm{M}(\mathrm{pH} 7)(\mathrm{w}: \mathrm{v}=1: 10)$. Sebelum diinokulasi serbuk karborundum ditaburkan pada bagian permukaan atas daun, lalu virus dioleskan ke permukaan daun sebanyak 1 kali dengan tangan menggunakan sarung tangan. Setelah sap (virus) mengering dilakukan pembilasan terhadap sisa-sisa sap yang masih melekat pada permukaan daun tanaman uji dengan menyemprotkan air steril. Selanjutnya dilakukan pengamatan setiap tiga hari sekali selama 30 hari.

5. Inokulasi virus pada tanaman inang: inokulasi virus pada tanaman inang adalah tahapan yang dilakukan setelah diperoleh hasil dari inokulasi pada tanaman indikator. Setiap tanaman anggrek diberi perlakuan sama dengan cara mengoleskan virus pada dua helai daun termuda yang telah membuka penuh. Selama waktu inkubasi dilakukan pengamatan untuk mengetahui respon diantara tanaman inang yang lebih cepat terinfeksi dengan adanya gejala penyakit.

6. Pengamatan: variabel yang diamati adalah analisis gejala penyakit, analisis kejadian penyakit, dan analisis ketahanan tanaman.

Data inokulasi ORSV pada tanaman indikator dan inang adalah data kualitatif dan kuantitatif. Data kualitatif disajikan dalam bentuk deskriptif dan didukung foto.

\section{HASIL DAN PEMBAHASAN}

1. Pengamatan Gejala Infeksi

Inokulasi ORSV pada masing-masing tanaman indikator dan tanaman inang dilakukan pada waktu yang berbeda-beda tergantung cepat atau lambatnya pertumbuhan tanaman dan ditandai cukup tidaknya jumlah daun. Respon tanaman setelah dilakukan inokulasi virus menunjukan bahwa ORSV dapat menginfeksi semua tanaman indikator dan tanaman uji dengan berbagai macam variasi gejala dan waktu inkubasi yang berbedabeda. Berdasarkan pengamatan, secara umum respon mulai muncul sekitar 2-3 minggu setelah dilakukan inokulasi pada semua tanaman.

Gejala infeksi ORSV yang sering ditimbulkan pada tanaman indikator diantaranya yaitu tembakau diawali dengan munculnya gejala klorotik pada hari ke-9 setelah inokulasi, selanjutnya pada hari ke-17 gejala berubah menjadi mosaik. Gejala mosaik merupakan gejala lanjutan dari gejala yang muncul sebelumnya yaitu klorotik, gejala ini menunjukan bahwa infeksi virus pada tanaman tembakau menjadi lebih parah. Pada hari ke-26 adanya variasi gejala yaitu terjadi perubahan bentuk daun (malformasi daun) merupakan gejala kelanjutan dari mosaik. Pada penelitian sebelumnya (Mahfut \& Daryono, 2020), juga diketahui bahwa infeksi ORSV pada tanaman tembakau akan muncul gejala klorotik, mosaik dan malformasi daun pada hari ke-5, ke-9 dan ke-12.

Gejala infeksi pada tomat hari ke-20 setelah inokulasi ditandai dengan munculnya gejala kerdil pada daun muda (stunting). Kemudian pada hari ke-30 gejala berubah menjadi mosaik yang menunjukan bahwa infeksi virus menjadi semakin parah. Selanjutnya pada hari ke-40 munculnya gejala malformasi daun yaitu adanya perubahan pada daun yang tidak sama pada bentuk semula. Pada penelitian sebelumnya (Listihani et al., 2018), juga diketahui bahwa infeksi ORSV pada tanaman tomat akan muncul gejala mosaik dan malformasi daun pada hari ke-4.

Timun menunjukan gejala nekrotik pada hari ke-12 yang ditandai dengan adanya bercak-bercak putih pada daun terbawah. Timun adalah tanaman indikator kedua yang memiliki gejala paling cepat terinfeksi terhadap ORSV setelah tembakau. Selanjutnya pada hari ke-30 gejala nekrotik tersebut semakin banyak dan melebar hampir menutupi seluruh permukaan daun. Hal ini menunjukan bahwa gejala nekrotik pada timun semakin 
parah. Pada penelitian sebelumnya (Listihani et al., 2018), diketahui bahwa infeksi ORSV pada tanaman timun menunjukan gejala klorotik dan mosaik pada hari ke-10 (Gambar 1).

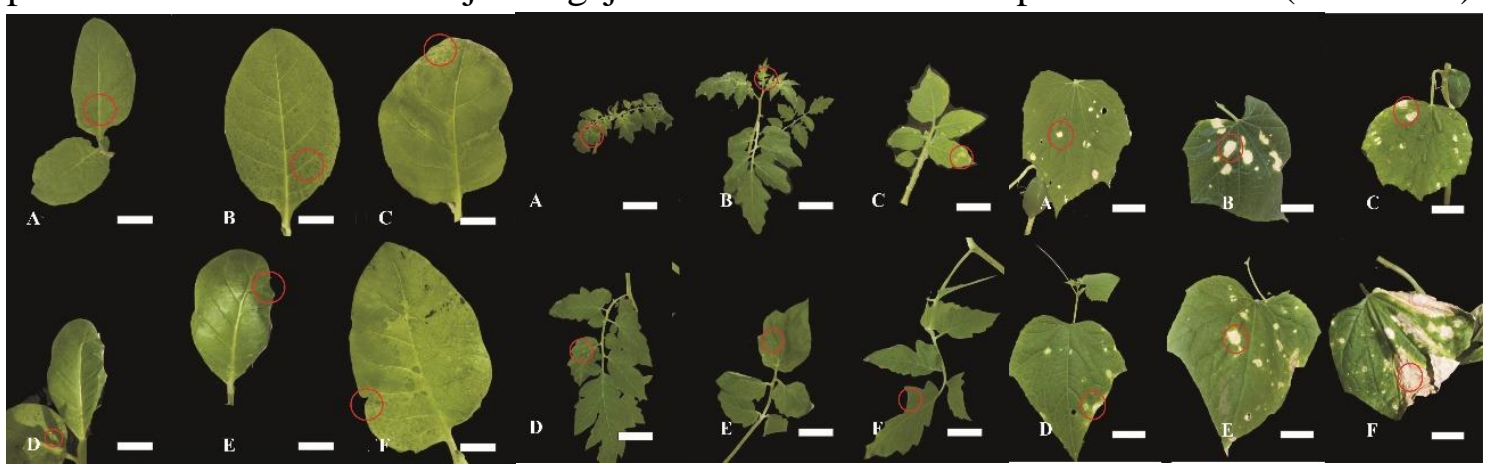

Gambar 1. Gejala infeksi ORSV pada Nicotiana tabacum: Klorotik (A dan B); Mosaik (C dan D); Malformasi daun (E dan F), Solanum lycopersicum: Stunting (A dan B); Mosaik (C dan D); Malformasi daun (E dan F), Cucumis sativus: Nekrotik (A dan F). Bar=1 cm

Gejala infeksi virus pada tanaman inang tidak menunjukan gejala sampai dengan hari ke-30. Selanjutnya dilakukan reinokulasi dan diamati kembali hingga gejala terlihat. Pada Phalaenopsis amabilis menunjukan gejala nekrotik pada hari ke-18. Pengamatan dilanjutkan sampai hari ke-30 dan menunjukan gejala nekrotik yang semakin parah. Pada penelitian sebelumnya (Mahfut \& Daryono, 2020), juga diketahui bahwa infeksi ORSV pada tanaman Phalaenopsis sp. menunjukkan gejala nekrotik pada hari ke-23.

Dendrobium Salaya Fancy menunjukkan gejala nekrotik pada hari ke-15. Gejala nekrotik pada Dendrobium lebih cepat terlihat dibandingkan pada Phalaenopsis. Berdasarkan hasil pengamatan gejala sampai dengan hari ke-25, gejala nekrotik berubah menjadi mosaik yang menunjukan infeksi ORSV pada Dendrobium semakin parah. Pada penelitian sebelumnya (Mahfut \& Daryono, 2020), diketahui bahwa infeksi ORSV pada tanaman Dendrobium sp. juga muncul gejala nekrotik dan mosaik pada hari ke-15 dan ke-23 (Gambar 2).

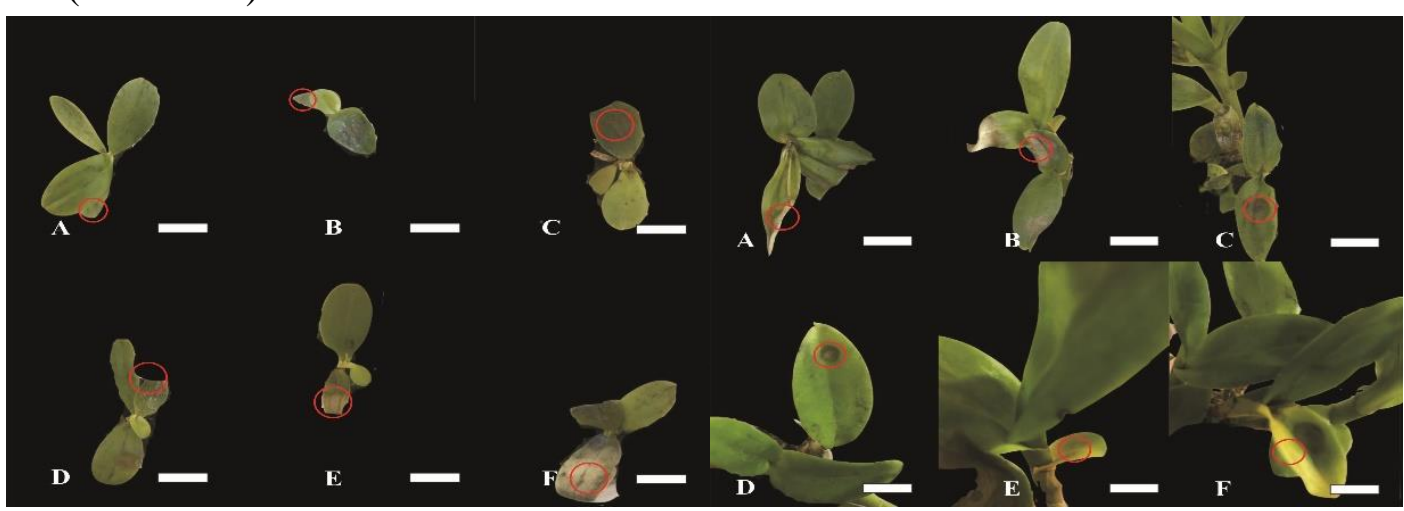

Gambar 2. Gejala infeksi ORSV pada Phalaenopsis amabilis; : Nekrotik dan Dendrobium Salaya Fancy; $O$ :Nekrotik, $\square$ : Mosaik. Bar $=1 \mathrm{~cm}$ 
2. Kejadian Penyakit

Hasil dari kejadian penyakit tanaman terhadap infeksi ORSV disajikan pada Tabel 1.

Tabel 1. Analisis kejadian tanaman terhadap infeksi ORSV

\begin{tabular}{cc}
\hline Jenis Tanaman & Kejadian Penyakit \\
\hline Nicotiana tabacum & $75 \%$ \\
Solanum lycopersicum & $75 \%$ \\
Cucumis sativus & $75 \%$ \\
Phalaenopsis amabilis & $80 \%$ \\
Dendrobium Salaya Fancy & $80 \%$ \\
\hline
\end{tabular}

Berdasarkan Tabel 1 diperoleh hasil bahwa masing-masing jenis tanaman memiliki respon yang sama yaitu kejadian penyakit $>40 \%$ yaitu $75 \%$ pada tanaman indikator dan $80 \%$ pada tanaman inang serta ditemukan adanya infeksi penyakit. Hal tersebut membuktikan bahwa inokulasi ORSV pada keseluruhan tanaman indikator dan tanaman inang berhasil dilakukan. Pada penelitian sebelumnya (Mahfut, 2020), juga diketahui bahwa inokulasi ORSV pada tanaman Phalaenopsis sp. dan Dendrobium sp. menunjukan kejadian penyakit $>40 \%$ dan ditemukan adanya infeksi penyakit.

3. Ketahanan Tanaman

Adapun hasil yang diperoleh dari analisis ketahanan tanaman terhadap infeksi ORSV disajikan pada Tabel 2.

Tabel 2. Analisis ketahanan tanaman terhadap infeksi ORSV

\begin{tabular}{cc}
\hline Jenis Tanaman & Respon Tanaman \\
\hline Nicotiana tabacum & Sangat Rentan \\
Solanum lycopersicum & Sangat Rentan \\
Cucumis sativus & Sangat Rentan \\
Phalaenopsis amabilis & Sangat Rentan \\
Dendrobium Salaya Fancy & Toleran \\
\hline
\end{tabular}

Berdasarkan tabel diatas maka diperoleh hasil bahwa seluruh jenis tanaman memiliki respon yang sama yaitu rentan terhadap ORSV. Pada penelitian sebelumnya (Mahfut et al., 2016; Mahfut dan Anggraeni, 2020), melaporkan bahwa Phalaenopsis merupakan tanaman inang jenis anggrek yang sangat rentan dan paling mudah terinfeksi ORSV.

\section{KESIMPULAN}

Hasil penelitian menunjukkan bahwa tanaman indikator dan tanaman inang memiliki gejala penyakit yang cukup parah dengan berbagai macam variasi gejala. Masing-masing tanaman memiliki respon yang sama, tanaman indikator memiliki kejadian penyakit $>40 \%$ yaitu $75 \%$ sedangkan tanaman inang dengan kejadian penyakit $>40 \%$ yaitu $80 \%$. Respon tanaman indikator dan inang terhadap ORSV yaitu sangat rentan, kecuali pada tanaman inang anggrek Dendrobium Salaya Fancy memiliki respon toleran terhadap ORSV. 


\section{DAFTAR PUSTAKA}

Koh, K.W., Lu, H.C., \& Chan, M.T. (2014). Virus Resistance in Orchid. Journal of Plant Science, 228: 2638.

Listihani., Damayanti, T.A., Hidayat, S.H., \& Wiyono, S. (2018). Karakteristik Molekuler Papaya Ringspot Virus Tipe P Pada Tanaman Mentimun di Jawa. J. Fitopatol. Indones, 14(3), 75-83.

Mahfut, \& Anggraeni, M. (2020). Evolusi Virus Anggrek di Indonesia. Prosiding Seminar Nasional Biologi di Era Pandemi COVID-19, 19 September 2020. Gowa. ISBN 978-602-72245-5-1, hal 1-5.

Mahfut, \& Daryono, B.S. (2019). Variation Symptoms and Resistance of Different Types on Orchids (Orchidaceae) against Odonttoglossum ringspot virus (ORSV) Infection. INSIST, 4 (2), 246-249.

Mahfut, Daryono, B.S., Joko, T., \& Somowiyarjo, S. (2016). Survey Odontoglossum ringspot virus (ORSV) yang Menginfeksi Anggrek Alam Tropis Di Indonesia. Jurnal Perlindungan Tanaman Indonesia, 20(1), 1-6.

Mahfut. (2020). Variation of Resistance Responses on Indicator Plants against Odontoglossum ringspot virus (ORSV) Infection. International Journal of Advanced Science and Technology, 29(3), 1178011785.

Matthews, R. (1992). Plant Fundamental of Plant Virology. California: Academic Press inc.

Muharam, A., Sulyo, Y., Rahardjo, I.B., Diningsih, E., \& Suryanah. (2013). Penyebaran Tobacco Mosaic Virus. Agroradix, 2(1), 2621-0665.

Navalienskie, M.J., Raugalas, \& Samuitie, M. (2005). Viral Desease of Flower Plants: Identification of Viruses Affecting Orchid (Cymbidium sp.). Jurnal Biologika, 2, 29-34. 